\title{
Regional Financial Model Mapping Independence to Fiscal in East Java
}

\author{
Syamsul Huda ${ }^{1}$, Wiwin Priana ${ }^{1} \&$ Zumrotul Fitriyah $^{1}$ \\ ${ }^{1}$ Develomeny Economic, Fakultas Ekonomi dan Bisnis (FEB) UPN Veteran Jakarta, Indonesia \\ Correspondence: Syamsul Huda, Lecturer in Develomeny Economic, Fakultas Ekonomi dan Bisnis (FEB) UPN \\ Veteran Jakarta, Indonesia.
}

Received: April 30, 2019

Accepted: May 30, 2019

Online Published: June 11, 2019

doi:10.5430/ijfr.v10n5p411

URL: https://doi.org/10.5430/ijfr.v10n5p411

\begin{abstract}
With the advent of Law No. 22 years 1999 set an authority and responsibility from central government to local government and UUNo.25 1999 governing financial between the center and regions, especially in the District city in East Java n local resources and reduce dependence of the center.

This study aims to determine the independence of the Regency / City in East Java analysis used is qualitative analysis, the analysis that are explained in the description or in the form of sentences and quantitative analysis, namely analysis using formulas and definite analysis. Quantitative analysis includes the analysis of the degree of fiscal decentralization determine the level of independence of regional and sectoral economic potential in the District East Java so that it can determine the level of fiscal independence and economic potential of the region. Results are expected to be used i pattern of the relationship between the central government and the government in the district / city in East Java as well as the formula right policy for future economic development.

From this research it is known that the city of Surabaya has a degree of fiscal autonomy for PAD at $48 \%$ of revenue while the region Gresik on the degree of fiscal autonomy degree enough and Sidoarjo district in degrees, please. There are 32 regions in the East dijawa degree of fiscal independence of each very less independent, meaning of Balance Funds as well as from centers of poropinsi
\end{abstract}

Keywords: fiscal decentralization, independence area

\section{Introduction}

Reforms that began several years ago in Indonesia have penetrated into all aspects of life. One is the governance, namely the relationship between the central government and local governments. Changes to the governance driven by a variety of public demands for more democratic government; thus demanding a change in the central government in order to give authority to local governments to manage their own regions, including the division of revenues between the central government and the regions (Devy Octaviana S, 2013: 1).

According to Kurniawan (2006), the adoption of Act No. 22 of 1999 on Regional Government and Law No. 25 of 1999 on Financial Balance between Central and Regional is a major step eagerly awaited by the region. The birth of this legislation is expected to be a cornerstone of the acceleration and the distribution of economic growth in the regions, which have perceived the existence of disparities in development between the center and regions. The law further enhanced by the issuance of Law No. 32 of 2004 on Regional Government and Law No. 33 of 2004 on Financial Balance between the Central Government and Local Government.

According Khusaini (2006), Yazdanjoo \& Fallahpour (2018) in accordance with Law No. 32 and 33 of 2004, the financial balance between the center and regions in implementing fiscal decentralization implies that the area was given the authority to utilize its own financial resources supported by the financial balance between the center and regions. Delivery of this authority must be accompanied by the delivery and transfer of financing. The most important source of financing is the source of financing, known as revenue (PAD), in which one of its main components is the revenue from the tax component area.

According to Waluyo (2005), the tax is basically the provision of wealth of the people, and or business entity to finance development activities undertaken by the state. Therefore, taxes are one source of state revenue collected under the legislation. 
Kurniawan (2006) mentions that the local tax is a tax that is managed by local governments, both provincial and district / city that is useful to support the acceptance of local revenues and the proceeds are included in the budget. The central government has been supporting the reception for local governments through the sharing of central taxes to support development in the region, among others, through the Land and Building Tax, Tax on Acquisition of Land and Building Tax in the State Personal Income and Income Tax Article 21.

Mahmudi (2010), Zhang \& Gao (2018) states that the tax legislation concerning the area has experienced several changes. Legislation in the field of local taxes, among others Drt Law No.11 of 1957 concerning the General Regulation of the Local Tax Law No. 18 of 1997 on Local Taxes and Levies. Then in 2009 the central government issued Law No. 28 Year 2009 on Regional Taxes and Levies replace Law No. 34 of 2000.

Local tax is a potential revenue source in the province of East Java. On Actual Data East Java Provincial Revenue earned from DPPAD East Java province, seen total amount of local taxes by the end of 2010 to 2014 which in 2010 amounted to Rp31.661.000.000,00 in 2011 amounted Rp.38.121.000.000,00 in 2012 of Rp.36.351.000.000,00 year 2013 by Rp.31.201.000.000,00 and 2014 amounted Rp.21.001.000.000,00 of total revenue shows local taxes potential to contribute funds for the original income. This raises the question whether the tax collection area is effective and efficient (Haseeb, Abidin, Hye \& Hartani, 2018; Bappeda of East Java, 2013).

In respect of the above data shows that fluctuations in tax revenues and even a decline in regional revenue that local governments affect the independence of East Java Province. Therefore it is necessary to know the further deepening of the decline data.

\section{Formulation of the Problem}

Based on the introduction and the fact that there is in east Java it can be formulated issues raised in this study as follows:

1. Does the financial potential mapping area in each district/city affect the financial independence of East Java.

2. Is the level of independence of Fiscal in districts/cities affect the independence of the East Java Provincial Finance.

3. Is the Economic Policy Recommendations in the District / City Government Finance affect the independence of East Java.

\section{Research Aim}

The purpose in this study was to determine the extent of the scope of research directed at the following objectives:

1. Identify potential Mapping Finance areas in each district // city in East Java.

2. Analyzing Factors Factors that Level Fiscal Independence in regencies / cities in East Java.

3. Formulate Recommendations Model of Economic Policy in the District / City in East Java.

\section{Theoretical Basis}

\subsection{Local Self-Reliance Index}

This index can be used to analyze the independence of a region to explore the sources of financial receipts from its own country. The ratio is used to measure the index. In this analysis, there are two kinds:

1. The ratio of revenue (PAD) to Total Regional Revenue (TPD)

2. Ratio of Tax Revenue and Non-Tax (BHPBP)

From this index can be seen how large an area can meet Incme area consists of five post is part of the remaining budget, Section PAD, Section Weighing Fund, Local Government Loans Section, and other legitimate acceptance. (Reksohadiprodjo, 2001: 155):

i. $\quad$ PIR Index $=$ PIR/TIR x $100 \%$

ii. Index Balances of Finace BF/TIR x 100\%

\subsection{Understanding Decentralization}

Decentralization means government by the Government delegation of authority to autonomous regions within the framework of the Unitary Republic of Indonesia. According to Law No. 5 of 1999, decentralization is a transfer of administrative services from the central government or of a local authority higher to lower local government to become regional services. 
Decentralization means giving a portion of the central government to local authorities to carry out and complete the matters which are the responsibility and concerns the interests of the region concerned (autonomy). Matters concerning the interests and responsibilities of an area, for example :

a. Public affairs and government

b. Faslitiws settlement services, and

c. Social and cultural affairs, religion and society (Elmi, 2002; Aimer, 2016; Zeyn, 2018).

Fiscal decentralization can be interpreted as a delegation of authority in the field of budget revenue or finance the previously centralized, both in the administration and utilization at or or by the central government. With the onset of the delegation of authority in part of the sources of state revenue to the local government, in the hope that these areas will be able to carry out routine tasks, public services, and increasing productive investments (capital investment) in the region (Ajani \& Igbokwe 2015).

Fiscal decentralization is mainly intended to transfer or delegate the sources of income and expenditure factors to the area by reducing government bureaucracy. By bringing government closer to the people, fiscal decentralization is expected to drive efficiency in the public sector, as well as public accountability, and transport in the provision of public services as well as transparent decision-making and democratic (Demelo, 2000; Xu \& Zhang,2018)

Implementation of fiscal decentralization would go well with reference to the following matters:

a. The existence of a capable central government in monitoring and low enforcement.

b. There's a balance between accountability and authority in the conduct of taxes and levies.

Fiscal decentralization should be followed by the ability of local governments to levy taxes (taxing power) The purpose is to develop a greater decentralization of planning and implementation of public services by combining local needs and conditions as well as to achieve the objectivity of social development, the economy at national and regional levels, improved planning, implementation and social and economic development budget is expected to be used more effectively and efficiently (Jermsittiparsert \& Sriyakul, 2014). To meet local needs.

\subsection{Fiscal Decentralization Indicators}

In discussing the fiscal decentralization indicator, there are three variables that are fiscal decentralization in Indonesia, the three variables are as follows:

a. decentralization Expenditure

Variable defined as the ratio of total expenditure. Each district / city (budget) there is total government spending (APBN) (Kerk and Waller, 1997, zhang and zou, 1998). This shows relative Zise government spending between local government and central government. Results of studies conducted Zhang and Zou (1998), indicates that this variable has a negative effect on economic growth. These results failed to implement that fiscal decentralization encourages economic growth in China, this may reflect that the government has limited resources to invest in the infrastructure sector. While the study conducted by Phillips and Woller (1997) also showed the negative effects of fiscal decentralization on economic growth in the developed countries. And they failed to explain the effect of fiscal decentralization on economic growth in developing countries.

\section{b. Development expenditure decentralization}

This variable is defined as the ratio of the total development expenditure of each county or city (APBD) to total national development expenditures (APBN) (Zhang and Zou, 1998; Wonyra, 2018; Akhir, et al. 2018). This variable indicates the relative magnitude of government spending on development between central and local governments. In addition, this variable also expresses the magnitude of development expenditure allocation between central and local governments. From this ratio can also be known whether local governments are in a good position to carry out public sector investment or not. If there is a positive relationship between these variables to economic growth, then the local government in a good position to invest in the public sector.

\section{c. Decentralization Reception}

This variable is defined as the ratio between the total acceptance of each county/city (budget) does not include subsidies to total government revenues (Phillips and Woller, 1997). This variable expresses the relative magnitude between local government revenue. 


\begin{tabular}{ll}
\hline PAD/TPD (\%) Regional Financial Capability & Interval scale Degree of Fiscal Decentralization \\
\hline 0.00 to 10.00 & Very Less \\
\hline 10.01 to 20.00 & Less \\
\hline $20.01-30.00$ & Medium \\
\hline 30.01 to 40.00 & Enough \\
\hline 40.01 to 50.00 & Good \\
\hline More 50.00 & Very Good
\end{tabular}

Source: UGM, 1991

To determine whether an autonomous region was able to organize and manage their own household, (Syamsi 1986: 199) confirms several sizes:

1. The ability of structural organization

The organizational structure of local government should be able to accommodate all the activities and tasks become a burden and responsibility total units along with that stuff fairly reflect the needs, the division of duties, powers and responsibilities are fairly clear.

2. The ability of local government officials

Local government officials should be able to carry out their duties in the care of the household have and regions .skill, moral discipline and honesty mutually support the achievement of objectives in the region craved.

3. The ability to encourage community participation.

Local government should be able to encourage people willing to participate in development activities.

4. The ability of local financial

local government should be able to finance all government activities and community development, as the implementation of the regulation and maintenance of his own household. Whatever, sources of funds, whether the PAD or any part of central government subsidies.

\section{d. Local Revenue Sources}

Finance area has a very important position and need to be recognized by the government. Alternative ways to get adequate finance has been considered by the government. It can be seen from the official explanation of the law No.22 of 1999 as b. So that the regions can manage their own household, then the area needs to be given resources adequate funding. But given than not all sources of financing can to the region, then the region is required to be the financial resources of its own based on the legislation in force (Aktug \& Iri 2018).

The financial resources of the area can be obtained through a variety of ways:

1. Local government can raise funds from local taxes which have been approved by the central government.

2. The Government region can take part in tax revenues collected by the central region, such a percentage of the central taxes.

3. Local governments can apply for loans from third parties, market, bank or central government

4. Local governments may receive a subsidy from the central government (Kaho, 1988:125).

Accordance with article 79 of Law No. 22 of 1999 and chapters 3, 4, 5 and article 6 of Law No. 25 of 1999, local revenue sources consist of the following:

\section{Local Revenue}

Revenues which indicates the ability of the area to collect the sources of funds to finance the activities of both routine and development

2. Balance Fund, consisting of:

a. Part of the reception area of land and building tax (PBB), Bea acquisition of land and buildings (BPHIB)

b. The general allocation fund (DAU) 
c. Special Allocation Fund (DAK)

3. Regional Loans

4. Other Local Revenue the Legal

e. Tax Revenue and Non-Tax (BHPBP)

Part revenue obtained from the reception area for the results of tax and non-tax sharing.

1. Tax Sharing

a. Land and Building Tax (PBB)

b. Bea acquisition of Land and Building (BPHTB)

2. For non-tax (natural resources)

f. Local donations

Donations / aid from the central government to local governments in the form of General Allocation Fund (DAU) and Special Allocation Fund (DAK).

g. Dana General Allocation

Another important point of the financial arrangements in accordance with Act No. 25/1999 is a provision in the form of an intergovernmental transfer from the center to the district and the city called by the General Allocation Fund (DAU) and Special Allocation Fund (DAK). DAU is a block grant given to all counties and cities for the purpose of filling the gap between capacity and fiscal needs, and distributed by formulas based on certain principles which generally indicates that the poor and backward areas should receive more than richer regions. In other words, an important goal is the DAU allocation within the framework of equalization ability to provide public services among local governments in Indonesia. Law No.25 / 1999 Article 7 outlines that the federal government is obliged to distribute at least $25 \%$ of Revenue land is in the form of DAU.

DAU calculation policy Fiscal Year (FY) 2003 uses a formula with the concept of Fiscal gap (fiscal gap) set out in Regulation 84/2001 as an amendment to the Regulation 104/2000 on Balance Fund (DAU is used in the calculation of FY 2002). In addition to the fiscal gap formula, calculation of DAU also determined by using a stabilizing factor (FP) in the form Minimum Allocation (AM)

h. Special Allocation Fund

DAK is earmarked for specific areas chosen for a special purpose. Therefore, allocation

\section{Research Methods}

\subsection{Operational Definition and Measurement of Variables}

In analyzing the parameters to be studied either know the potential of the region as well as to determine the region's autonomy Variable Operational definition is as follows:

a. Local Revenue (PAD) is a local government revenue derived from sources of local revenue are levied by local regulations in accordance with the law, which includes local taxes, levies, results corporate have area and the results of the management of capital of the region, as well as other -Other PAD units reserch from the center of the DAK and DAK

\subsection{Types and Sources of Data}

Type of data

The data used in this research is secondary data, drawn from a particular year

Data source

Sources of data obtained from the Statistical Office of East Java, and East Java Bappeda

5.3 Mechanical Analysis

Local Self-Reliance Index

In this analysis, there are three kinds:

1. Rasio revenue (PAD) to Total Regional Revenue (TPD) Balanced funds.

2. Rasio. 


\section{Research Result}

\subsection{Analisa Degree of Fiscal Decentralization}

In the analysis of regional income will be displayed region reception area and cities inEast Java .For more $\mathrm{j}$ can be seen the following table

Table 1. Fiscal index reception regency / city in East Java in 2015

\begin{tabular}{|c|c|c|c|c|c|}
\hline $\begin{array}{l}\text { Region/ } \\
\text { Municipal }\end{array}$ & $\begin{array}{l}\text { Total Income } \\
\text { Region } \\
(000)\end{array}$ & $\begin{array}{l}\text { Pure Income } \\
\text { Region (PAD) } \\
(000)\end{array}$ & $\begin{array}{l}\text { Dana Perimbangan } \\
\text { (Balance Funding) } \\
(000)\end{array}$ & $\begin{array}{l}\text { Indeks } \\
\text { PIR } \\
(\%)\end{array}$ & $\begin{array}{l}\text { Indeks } \\
\text { Bance of } \\
\text { Fund } \\
(\%)\end{array}$ \\
\hline 1. Kota Surabaya & 7.304 .836 .873 & 3.520 .137 .339 & 1.536 .796 .757 & 48,18 & 19,69 \\
\hline 2. Kota Kediri & 1.432 .324 .497 & 166.436 .404 & 770.952 .510 & 11,62 & 53.82 \\
\hline 3. Kab. Sidoarjo & 3.702 .781 .216 & 1.090 .575 .14 & 1.449 .353 .252 & 29,45 & 39,14 \\
\hline 4. Kab. Gresik & 2.565 .135 .034 & 842.196 .737 & 1.131 .468 .608 & 32.83 & 44,10 \\
\hline 5. Kab. Malang & $3.303 . .969 .223$ & 333.189 .098 & 1.895 .537 .664 & 10,08 & 57,37 \\
\hline 6. Kota Malang & 1.821 .417 .126 & 353.424 .747 & 931.505 .593 & 19,385 & 51,14 \\
\hline 7. Kab. Banayuwangi & 2.572 .207 .223 & 249.030994 & 1.469 .636 .765 & 9,68 & 57,11 \\
\hline 8. Kab. Jember & 3.129 .650 .675 & 508.051 .017 & 1.863 .099 .834 & 16,21 & 59,53 \\
\hline 9. Kab. Bojonegoro & 3.195 .069 .711 & 262.951 .712 & 2.144 .452 .866 & 8,20 & 67,1 \\
\hline 10. Kab. Tuban & 1.939 .022 .483 & 260.939 .261 & 1.096 .825 .264 & 13,40 & 56,52 \\
\hline 11. Kab. Mojokerto & 2.230 .693 .946 & 400.009 .300 & 1.084 .684 .979 & 17,93 & 48,60 \\
\hline 12. Kab. Tulung agung & 2.213 .019 .823 & 213.010 .206 & 1.286 .442 .394 & 9,62 & 58,11 \\
\hline 13. Kab. Pasuruan & 2.480 .405 .639 & 372.454 .140 & 1.286 .442 .394 & 15,0 & 51,85 \\
\hline 14. Kab. Kediri & 2.458 .683 .034 & 272.923 .275 & 1.319 .841 .229 & 11,06 & 53,66 \\
\hline 15. Kab. Probolinggo & 2.121 .341 .946 & 184.19 .6571 & 1.141 .721 .604 & 8,67 & 53,79 \\
\hline 16. Kab. Jombang & 2.103 .180 .775 & 256.125 .950 & 1.184 .405 .880 & 12,17 & 56,300 \\
\hline 17. Kab. Lumajang & 1.897 .958 .994 & 170.242 & 1.118 .111 .139 & 8,96 & 58,93 \\
\hline 18. Kab. Blitar & 2.065 .948 .903 & 176.039 .479 & 1.231 .046 .036 & 8,52 & 59,61 \\
\hline 19. Kab. Lamongan & 2.222 .799 .102 & 266.767 .894 & 1.259 .978 .025 & 11,97 & 56,66 \\
\hline 20. Kab. Sumenep & 2.015 .840 .671 & 166.654 .328 & 1.309 .105 .178 & 8,23 & 64,96 \\
\hline 21. Kab. Nganjuk & 2.132 .109 .612 & 237.473 .871 & 1.175 .871959 & 11,11 & 55,11 \\
\hline 22. Kab.Situbondo & 1.549 .938 .736 & 125.963 .802 & 1.002 .450 .765 & 8,06 & 64,68 \\
\hline 23. Kab. .Bangkalan & 1.781 .003 .956 & 122.079 .311 & 1.137 .833 .827 & 6,85 & 63,84 \\
\hline 24. Kab. Ponorogo & 1.890 .938 .986 & 177.247 .642 & 1.172 .450 .159 & 9,36 & 62,01 \\
\hline 25. Kab. Magetan & 1.609 .326 .079 & 122.839 .547 & 978.442 .223 & 7,58 & 60,78 \\
\hline 26. Kab. Ngawi & 1.766 .878 .003 & 138.773 .976 & 1.107 .605 .839 & 7,81 & 62,68 \\
\hline 27. Kab. Bondowoso & 1.611 .254 .065 & 122.173 .828 & 1.001 .040 .533 & 7,57 & 62.13 \\
\hline 28. Kab. Madiun & 1.522 .302 .830 & 128.526 .430 & 971.080 .928 & 8,40 & 63,79 \\
\hline 29. Kab.Trenggalek & 1.620 .457 .377 & 124.094 .454$. & 1.020 .820 .215 & 7,65 & 62,96 \\
\hline 30. Kab. Sampang & 1.474 .017 .178 & 121.298 .115 & 999.734 .485 & 8,20 & 67,77 \\
\hline 31. Kota Madiun & 989.473 .907 & 111.379 .359 & 593.152 .373 & 11,22 & 59,95 \\
\hline
\end{tabular}




\begin{tabular}{llllll}
\hline 32. Kab.Pamekasan & 1.819 .566 .127 & 125.125 .991 & 1.045 .630 .754 & 6,87 & 57,44 \\
\hline 33. Kota Probolinggo & 894.026 .083 & 108.620 .977 & 756.2732 .181 & 12,08 & 84,56 \\
\hline 34. Kota Batu & 917.333 .704 & 80.150 .000 & 554.901 .356 & 8,72 & 60,41 \\
\hline 35. Kab/ Pacitan & 1.272 .572 .005 & 89.469 .532 & 833.044 .603 & 6,99 & 65,48 \\
\hline 36. Kota Mojokerto & 852.099 .820 & 92.842 .136 & 593.338 .493 & 10,79 & 69,60 \\
\hline 37. Kota Pasuruan & 2.480 .405 .639 & 92.842 .136 & 1.315 .925 .847 & 3,70 & 53,02 \\
\hline 38. Kota Blitar & 784.167 .167 .165 & 82.436 .369 & 536.976 .838 & 10,45 & 68,36 \\
\hline
\end{tabular}

Source: BPS

From the table above districts and cities in East Java which has the biggest PAD are Surabaya city by $48.18 \%$, and $32.83 \%$ for Gresik, Sidoarjo regency amounting to $29.49 \%$.

While counties and cities in East Java which has the largest equalization fund Kota Probolinggo seebesar Mojokerto $84.56 \%$ by $69.60 \%, 67.77 \%$ Sampang Bojonegoro by 67.10 by $68.36 \%$ Blitar City Sumenep regency and kabupatan Situbondo by $64 \%$, Bangkalan Regency and Regency Madiu by more than $63 \%$.

Table 2. The degree of decentralization

\begin{tabular}{|c|c|}
\hline \multirow[t]{2}{*}{ Region/Municipal } & Donation PI R /PAD 40-50\% \\
\hline & Degree of desentralization fiscal Good.(Baik) \\
\hline \multirow[t]{3}{*}{ 1.Surabaya } & $48,18 \%$ \\
\hline & Donation PIR 30,01-40,005 \\
\hline & DERJAT DESENTRALIZATION ENOUGH (Cukup) \\
\hline \multirow[t]{3}{*}{ 1.Gresik Region } & $32,83 \%$ \\
\hline & Donation of PAD 20,01-30,00\% \\
\hline & Degree of Desentralization of Moderate (sedang) \\
\hline \multirow[t]{3}{*}{ 1. Sidoarjo Region } & $29,49 \%$ \\
\hline & Donation PIR/PAD 10,01-20,00\% \\
\hline & Degree desentralization less (kurang) \\
\hline 1. Mojokerto Region & $17,92 \%$ \\
\hline 2. Probolinggo Municipal & $12.02 \%$ \\
\hline 3. Madiun Municipal & $11,22 \%$ \\
\hline 4. Kabupaten Nganjuk & $11,11 \%$ \\
\hline 5. Mojokerto Municipal & $10,79 \%$ \\
\hline \multirow[t]{2}{*}{ 6. Blitar Municipal } & $10,45 \%$ \\
\hline & $00,00-10.00 \%$ Desentralization Very Less ( Sangat Kurang) \\
\hline \multicolumn{2}{|c|}{29 Region/Munipal in East Jawa } \\
\hline \multicolumn{2}{|c|}{ - $\quad$ Probolinggo Region $(9.36 \%)$} \\
\hline \multicolumn{2}{|c|}{ - $\quad$ Pasuruan Municipal (3.7\%) } \\
\hline
\end{tabular}




\subsection{Analysis PIR/PAD, Taxes/Pajak 2 and Retribution/Retribusi}

Table 3. Donation taxes and levies in Surabaya, Sidoarjo and Gresik in 2015

\begin{tabular}{llll}
\hline Region/Municipal & PIR/PAD (000) & Taxes/Pajak (000) & Levies/Retribusi (000) \\
\hline Surabaya & 3.520 .137 .339 & $2.679 .378 .00(76.10 \%)$ & $302.514 .834(8.57 \%)$ \\
\hline Gresik & 842.196 .737 & $410.455 .500(48.69 \%)$ & $228.946 .834(27.07 \%)$ \\
\hline Sidoarjo & 1090.575 .714 & $656.653 .999(60.18 \%)$ & $97.650 .879(8.89 \%)$ \\
\hline
\end{tabular}

Source: BPS.

\section{Conclusions and Recommendations}

\subsection{Conclusion}

From the above data that the contribution of PAD in regencies / cities in East Java, which exceeds $25 \%$ of the reception area is the area in 2015:

1. Kota Surabayai PIR plugs $48.18 \%$ degree of decentralization Good

2. Gresik $32.83 \%$ degree of decentralization enough

3. Sidoarjo regency $29.49 \%$ Average Degree of Decentralization

The local area with PAD have turned out the area adjacent to Surabaya with kotributions GDRP sector is the sector of Trade and Industry is due to the elasticity of industry and trade sector support and contribute greatly to regional income. 3 of PAD in the area's largest donation came from Surabaya City Tax Contribution Tax on revenue of 76.10\%, 8.57\% Levy Tax Contribution Sidoarjo regency For revenue of 60.18\%, 8.89 Levy.\% Gresik Texes against PIR 48.69\% and amounted to $27.07 \%$ contribution levies. Surabaya area including Good financial management in financial management. Sidoarjo regency end of the financial management of the regions in the word i Good enough (32.15\%). Average Gresik including the category average (24.67\%), in the area of financial management.

\subsection{Recomendation}

East Java regional governments should encourage the agricultural sector and other sectors to be increased in order to increase revenues and districts and improving welfare.

\section{References}

Ahmed, U., Khalid, N., Ammar, A., \& Shah, M. H. (2017). Assessing moderation of employee engagement on the relationship between work discretion, job clarity and business performance in the banking sector of Pakistan. $\begin{array}{lllll}\text { Asian Economic } & \text { Find }\end{array}$ https://doi.org/10.18488/journal.aefr.2017.712.1197.1210

Aimer, N. M. M. (2016). The effects of fluctuations of oil price on economic growth of Libya. Energy Economics Letters, 3(2), 17-29. https://doi.org/10.18488/journal.82/2016.3.2/82.2.17.29

Ajani, E. N., \& Igbokwe, E. M. (2015). Assessment of human capital attributes influencing occupational diversification among rural women in Anambra State, Nigeria. International Journal of Sustainable Agricultural Research, 2(2), 31-44. https://doi.org/10.18488/journal.70/2015.2.2/70.2.31.44

Akhir, R. M., Ahmad, S. N. B., Ahmad, H., \& Hashim, N. A. (2018). Staying or Leaving? The Influence of Employees' Engagement towards Turnover Decision Among Employees of A Semi-Government Organization in Malaysia. American Journal of Social Sciences and Humanities, 3(1), 55-62. https://doi.org/10.20448/801.31.55.62

Aktug, Z. B., \& Iri, R. (2018). The Effect of Motor Performance on Sportive Performance of Children in Different Sports Branches. Asian Journal of Education and Training, 4(2), 75-79. https://doi.org/10.20448/journal.522.2018.42.75.79

Bastian. (2001). Manual Akuntasi Keuangan Pemerintah Daerah 2001. Penerbit BPFE, Yogyakarta.

Dasril, H., \& Hessel. (2004). Kebijakan \& Manajemen Keuangan Daerah. Penerbit YPAPI,Yogyakarta. 
Elmi, B. (2002). Keuangan Pemerintah Daerah Otonom di Indonesia. Penerbit Universitas Indonesia, UI Press, Jakarta.

Fuad. (2004). Analisis Faktor-Faktor Yang Mempengaruhi Pendpatan Asli Daerah di Jawa Timur,Skripsi. Fakulias Ekonomi Universitas Pembanggunan Nasional "Veteran”Jawa Timur, Surabaya.

Haseeb, M., Abidin, I. S. Z., Hye, Q. M. A., \& Hartani, N. H. (2018). The Impact of Renewable Energy on Economic Well-Being of Malaysia: Fresh Evidence from Auto Regressive Distributed Lag Bound Testing Approach. International Journal of Energy Economics and Policy, 9(1), 269-275.

Jermsittiparsert, K., \& Sriyakul, T. (2014). The Development of Population Potential and National Power by Elevating the Professional Standard for Sport Coaches. Asian Social Science, 10(10), 188-198. https://doi.org/10.5539/ass.v10n10p188

Kaho, J. R. (2005). Prospek Otonomi Daerah,edisi pertama. Penerbit PT. Raja Grafindo Persada, Jakarta.

Khusaini. (2006). Ekonomi Publik,Desentralisasi Fiskal dan Pembangunan Daerah. Penerbit BPFE UNIBRAW, Malang.

Kuncoro, M. (2004). Otonomi \& Pembangunan Daerah Reformasi, Perencanaan, Strategi, dan Peluang. Jakarta: Penerbit Erlangga.

Riduansyah. (2003). Kontribusi Pajak Daerah dan Restribusi Daerah Terhadap Pendapatan Asli Daerah (PAD) dan Anggaran Pendapatan dan Belanja Daerah(APBD) guna Mendukung Pelaksanaan Otonomi daerah. https://doi.org/10.7454/mssh.v7i2.51

Saragih, P. (2003). Desentralisasi Fiskal dan Keuangan Daerah Dalam Otonomi. Jakarta,Penerbit Ghalia Indonesia.

Syamsi, I. (1993). Dasar-Dasar Kebijaksanaan Keuangan Negara. Cetakan Kedua, Penerbit PT. Bina Aksaram Jakarta.

Wonyra, K. O. (2018). Industrialization and Economic Growth in Sub-Saharan Africa: The Role of Human Capital in Structural Transformation. Journal of Empirical Studies, 5(1), 45-54. https://doi.org/10.18488/journal.66.2018.51.45.54

Xu, Q., \& Zhang, H. (2018). Optimal Bid Strategies in Crowdsourcing Contest Based on Multi-Attribute Auctions. International Journal of Emerging Trends in Social Sciences, 4(2), 67-74. https://doi.org/10.20448/2001.42.67.74

Yazdanjoo, S., \& Fallahpour, H. (2018). A Study on the Correlation between Creative Thinking of Iranian EFL Learners and Using Metaphor in Descriptive Writing Tasks. International Journal of English Language and Literature Studies, 7(2), 32-44. https://doi.org/10.18488/journal.23.2018.72.32.44

Zeyn, E. (2018). The Effect of Internal Audit Quality on Financial Accountability Quality at Local Government. Journal of Accounting, Business and Finance Research, 4(2), 74-82.

Zhang, K., \& Gao, J. (2018). Coordination Strategy of Dual-Channel Supply Chain for Fresh Product Under the Fresh-Keeping Efforts. International Journal of Emerging Trends in Social Sciences, 4(2), 75-85. https://doi.org/10.20448/2001.42.75.85 